\title{
Monitoring and assessment of endangered UNESCO World Heritage Sites using space technology: a case study of East Rennell, Solomon Islands
}

\author{
Sijia Huo ${ }^{1,2}$, Mengmeng Wang ${ }^{3}$, Guolong Chen ${ }^{1,2^{*}}$ (D) Huiqin Shu ${ }^{1,2}$ and Ruixia Yang ${ }^{1,2}$
}

\begin{abstract}
Space technology offers effective tools to monitor the status of World Natural Heritage sites. East Rennell Island, which covers approximately 37,000 hectares (ha) and a marine area extending three nautical miles into the sea, was added to the list of endangered World Natural Heritage sites in 2013. Deforestation and natural disasters have increasingly threatened sustainable development on the island. Based on analyses of multi-source time series of remote sensing data (e.g., MODIS and Worldview), the forest cover change on Rennell Island from 2000 to 2020 and its future trends were mapped and analysed using Sen + Mann-Kendall and Hurst index models. A land cover classification system derived from high-resolution Worldview images was developed as a baseline for monitoring and analysing future forest cover changes on the island. Our results showed that (1) the areas of vegetation degradation and improvement were basically equal from 2000 to 2020. (2) The forest cover change trend had weak continuity, and significant improvements could be achieved in areas with damaged vegetation given sufficient protection measures and financial input. (3) This heritage site has a strong vegetation regeneration ability, and human activities such as mining, logging, and road construction, which could greatly disturb the unique ecosystem, should be restricted.
\end{abstract}

Keywords: World Heritage, East Rennell, Solomon Island, Vegetation Change, Multi-source Remote Sensing Data

\section{Introduction}

The 3S space technologies are characterised by real-time and high-precision positioning, multi-temporal data acquisition with different resolutions, and intelligent and efficient data management strategies; these data have the potential for use in World Heritage Sites [1-3]. There is an urgent need to continuously monitor these and implement protective measures. The UNESCO World Heritage Center supervises and helps the government of the Solomon Islands improve the protection and management

\footnotetext{
*Correspondence: chenguolong_cgl@163.com

${ }^{1}$ International Centre on Space Technologies for Natural and Cultural Heritage, The Aerospace Information Research Institute, Chinese Academy of Sciences, Beijing 100094, China

Full list of author information is available at the end of the article
}

of the East Rennell World Heritage Site (ERWHS) by providing funding and technical coordination, including entrusting the International Centre on Space Technologies for Natural and Cultural Heritage (HIST), a Category-II centre under the auspices of UNESCO, to facilitate the monitoring of changes in the forest cover on Rennell Island. HIST is the first UNESCO centre to apply space technologies to monitor and preserve natural and cultural heritage sites. The centre is hosted by the Aerospace Information Research Institute of the Chinese Academy of Sciences. Cultural and natural heritage sites with high universal value, especially those included on the list of endangered World Heritage Sites, are threatened by natural forces and human actions [4]. HIST has employed space technology to monitor changes due to these factors on Rennell Island, using high-resolution
Springer Open

(c) The Author(s) 2021. Open Access This article is licensed under a Creative Commons Attribution 4.0 International License, which permits use, sharing, adaptation, distribution and reproduction in any medium or format, as long as you give appropriate credit to the original author(s) and the source, provide a link to the Creative Commons licence, and indicate if changes were made. The images or other third party material in this article are included in the article's Creative Commons licence, unless indicated otherwise in a credit line to the material. If material is not included in the article's Creative Commons licence and your intended use is not permitted by statutory regulation or exceeds the permitted use, you will need to obtain permission directly from the copyright holder. To view a copy of this licence, visit http://creativecommons.org/licenses/by/4.0/. The Creative Commons Public Domain Dedication waiver (http://creativeco mmons.org/publicdomain/zero/1.0/) applies to the data made available in this article, unless otherwise stated in a credit line to the data. 
data from 2015 as a benchmark for evaluating future changes on the island [5]. This paper presents a study on forest vegetation cover changes from 2000 to 2020 in one of the world's endangered heritage sites-East Rennell Island in the Solomon Islands-and establishes a land classification system to monitor and predict future changes. Changes in forest cover are expected to provide scientific support for the restoration and protection of the world's endangered heritage sites.

The Solomon Islands belong to Melanesia, which is located in the South Pacific Ocean, east of Papua New Guinea. It is classified as a least developed country (LDC) and a small island developing state (SIDS).

East Rennell Island makes up the southern third of Rennell Island, the southernmost island in the Solomon Island Group in the western Pacific Ocean (Fig. 1). East Rennell Island was added the World Heritage List in 1998 [6] and has been included on the list of endangered sites since 2013 due to logging, which adversely affects the heritage site's ecosystem. The World Heritage Committee determined that although the logging is taking place outside the core area of the heritage site, it is threatening East Rennell's outstanding universal value; therefore, the committee has asked the national authorities to provide an impact assessment of logging on the island.
East Rennell demonstrates significant ongoing ecological and biological processes and is an important site for studying island biogeography. In particular, the island is an important steppingstone in the migration of species, especially avifauna, in the western Pacific Ocean; it also provides an area for speciation processes and evolution of these species. The unmodified forest vegetation contains floral elements from the less biodiverse Pacific Islands to the east and the much richer Melanesian flora to the west. Rennell Island has a high number of endemic species, particularly among its avifauna, and harbours ten endemic plant species [7].

The wildlife of Rennell Island includes 11 species of bats (one endemic) and 43 species of breeding land and water birds (with four species and nine endemic subspecies, respectively). The invertebrate life on the island is also rich, with 27 species of land snails (seven endemics) and approximately 730 insect species, many of which are endemic. The flora of Lake Tengano is dominated by more than 300 species of diatoms and algae, some of which are endemic. There is also an endemic sea snake in the lake [8].

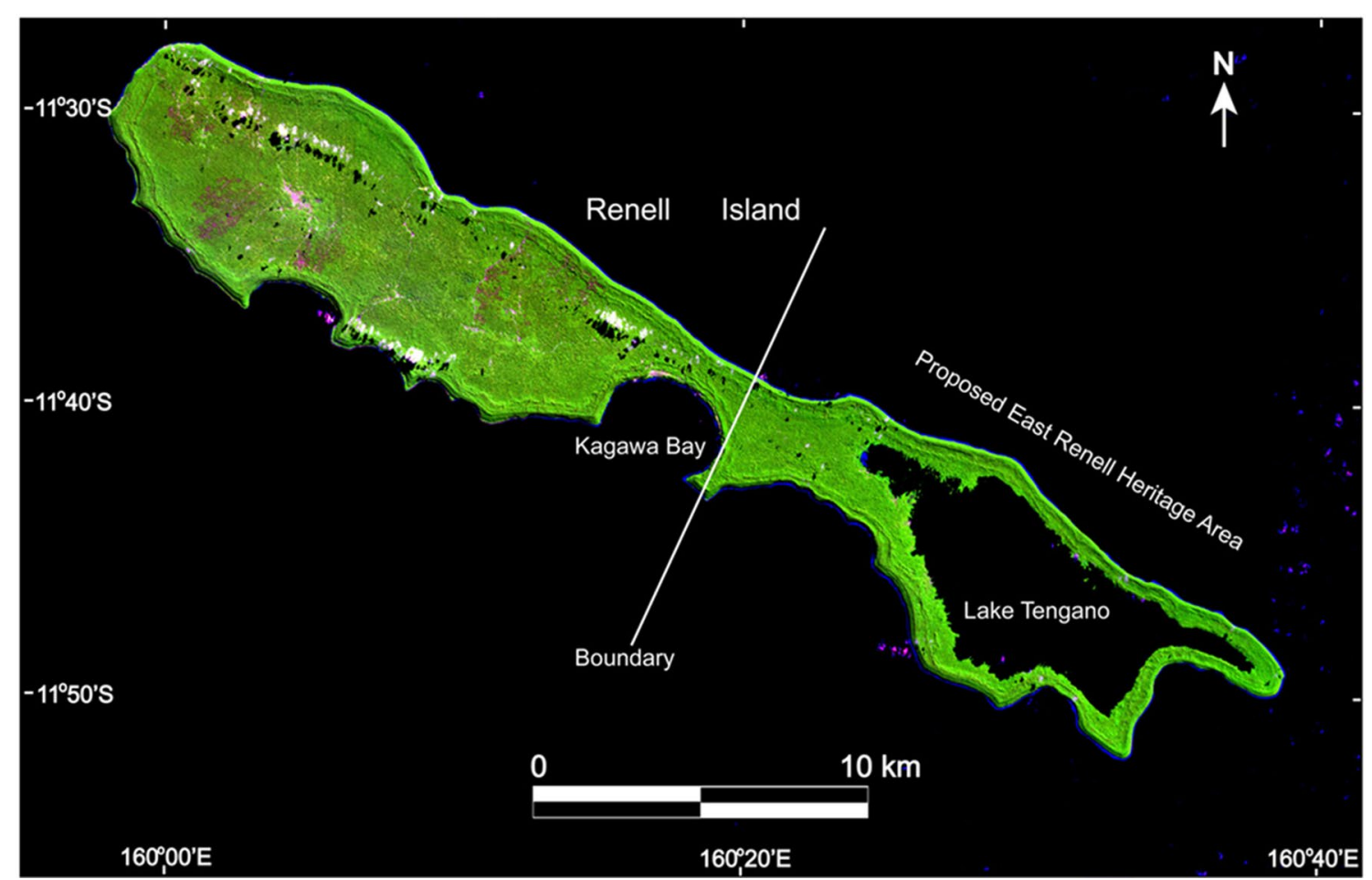

Fig. 1 Landsat 8 image of Rennell Island showing the vegetation coverage of the East Rennell heritage site on 07 June 2016 


\section{Data and methods}

Data on the relative distributions of endemic and native species of Rennell Island are lacking or non-existing, making systematic assessments of threats and their impacts difficult. Risk monitoring and preventive diagnosis of threats to heritage sites in any given ecosystem are complex and challenging tasks [9]. We take advantage of long-term earth observations to monitor forest cover change and classify land cover; thus, remote sensing data provide an effective assessment tool to protect Rennell Island.

\section{Data}

Rennell Island, as a tropical island, is often obscured by dense clouds, which have a significant impact on vegetation monitoring and land cover classification from optical remote sensing data. We collected multisource remote sensing data and selected high-quality data with no or few clouds, and we obtained 432 moderate-resolution imaging spectroradiometer (MODIS) scenes with

Table 1 Satellite remote sensing data covering Rennell Island

\begin{tabular}{llcl}
\hline Data source & Resolution & $\begin{array}{l}\text { Number of } \\
\text { scenes }\end{array}$ & Acquisition period \\
\hline MODIS & $250 \mathrm{~m}$ & 432 & $2000 / 02 / 18-2020 / 08 / 27$ \\
Landsat 7 & $30 \mathrm{~m} / 15 \mathrm{~m}$ & 2 & $2012 / 06 / 05,2013 / 04 / 21$ \\
Landsat 8 & $30 \mathrm{~m} / 15 \mathrm{~m}$ & 5 & $2014 / 03 / 15,2015 / 08 / 09$, \\
& & & $2016 / 06 / 07$, \\
& & & $2016 / 06 / 24$, \\
& & $2017 / 03 / 07$, & $2018 / 06 / 14$ \\
Worldview & $2 \mathrm{~m} / 0.5 \mathrm{~m}$ & 20 & $2014 / 03 / 19-2015 / 10 / 03$ \\
Hansen & $30 \mathrm{~m}$ & 7 & \\
\hline
\end{tabular}

16 day synthetic normalized difference vegetation index (NDVI) data (250 $\mathrm{m}$ ground-resolution) MOD13Q1, 7 Landsat 7 and Landsat 8 scenes (30 m ground resolution), 20 Worldview scenes, and 7 Hansen scenes (Table 1) between 2000 and 2020. The MOD13Q1 data were used to analyse the dynamic changes in NDVI on Rennell Island, and the other data were used mostly to analyse the land cover changes on Rennell Island.

\section{Methods}

Google Earth's historical view provided images of Rennell Island from 2000 to 2020. Although the resolution of these images is relatively rough, they still helped us to quickly locate areas with obvious changes. Before data analysis, the original data were preprocessed (Fig. 2). The technical framework adopted for image interpretation and mosaicking (combining individual images to obtain a composite image for the whole island) is shown in Fig. 2.

For the high-resolution Worldview images of Rennell Island, ortho-correction was performed by PCI GXL software, then the Fmask algorithm was used to mask cloud-covered areas. The ortho images were then inlaid on the study site after cloud removal by Inpho OrthoVista software to generate cloud-free high-resolution remote sensing images covering the research area.

NDVI, which reflects the typical spectral characteristics of vegetation, is the most widely used vegetation index. There is a significant linear correlation between vegetation coverage and NDVI [10]. When applying a dimidiate pixel model, due to the complexity of the land surface, the selection of two extreme NDVI points at the global scale can cause great uncertainty in the estimation of vegetation coverage [11]. The maximum

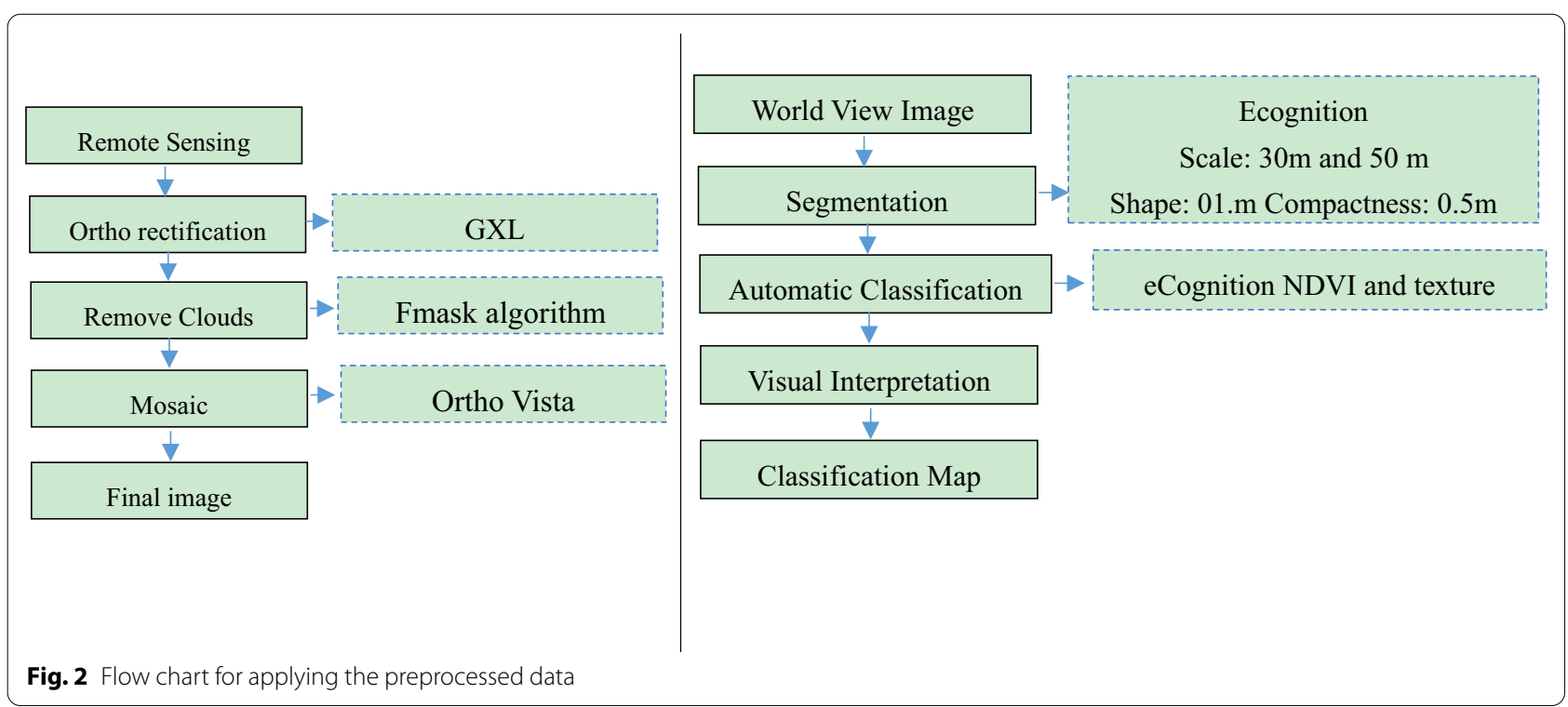


and minimum values of NDVI obtained from remote sensing images of the study area were selected as the NDVI values of pure vegetation and bare soil [12]:

$$
\begin{aligned}
& N D V I=\frac{D N_{\text {nir }}-D N_{\text {red }}}{D N_{\text {nir }}-D N_{\text {red }}} . \\
& P=\frac{\left(N D V I-N D V I_{\text {min }}\right)}{\left(N D V I_{\text {max }}-N D V I_{\text {min }}\right)}
\end{aligned}
$$

where NDVI is the normalized vegetation index; $D N_{n i r}$ is near-infrared reflectance; $D N_{r e d}$ c is red reflectance; $\mathrm{P}$ is vegetation coverage; $N D V I_{\max }$ is the NDVI value of pure vegetation in the study area; and $N D V I_{\min }$ is the NDVI value of bare soil in the study area.

After applying the vegetation coverage division method, the vegetation coverage in the study area was divided into five classes, as shown in Table 2. Despite concerns about work on logging and mining concessions, raw forest coverage remained high across the island area, especially on East Rennell Island, which maintained the highest forest cover.

The Theil-Sen slope analysis and Mann-Kendall test model (Sen and Mann-Kendall, respectively) have advantages over regression analysis and correlation coefficient analysis for trend analysis, namely, they do not require data that follow a normal distribution or have small variances. These methods can effectively reflect long-term dynamic vegetation characteristics [13], which is important when studying climate change, hydrology, and meteorology. Sequential NDVI images between 2000 and 2020 were selected for analysis.

The Sen trend analysis formula is as follows:

$$
\beta=\operatorname{Median}\left(\frac{x_{j}-x_{i}}{j-i}\right), \forall j>i
$$

where $x_{i}$ refers to the ith NDVI data point in the time series of NDVI data on Rennell Island and $x_{j}$ reflects similar data. Positive and negative values of $\beta$ reflect upward and downward trends, respectively, where $\beta>0$ indicates an increasing NDVI trend, $\beta=0$ indicates an unchanged NDVI trend, and $\beta<0$ indicates a decreasing NDVI trend.

Table 2 Division of vegetation coverage

\begin{tabular}{ll}
\hline$P \leq 0.2$ & Lowest vegetation coverage \\
$0.2<P \leq 0.4$ & Low vegetation coverage \\
$0.4<P \leq 0.6$ & Moderate vegetation coverage \\
$0.6<P \leq 0.8$ & High vegetation coverage \\
$P>0.8$ & Highest vegetation coverage \\
\hline
\end{tabular}

The procedure for applying the Mann-Kendall test to determine the significance of the trend is described below.

For time series $\mathrm{T}$, the statistic $\mathrm{T}_{\mathrm{S}}$ is calculated by formula (4):

$$
\begin{aligned}
& T_{s}=\sum_{i=1}^{n-1} \sum_{j=i+1}^{n} \operatorname{sgn}\left(x_{j}-x_{i}\right) \\
& \operatorname{sgn}\left(x_{i-} x_{j}\right)= \begin{cases}+1, & x_{j}-x_{i}>0 \\
0, & x_{j}-x_{i}=0 \\
-1, & x_{j}-x_{i}<0\end{cases}
\end{aligned}
$$

where $x_{j}$ is the $j$ th data point in the time series, $n$ is the number of data samples, and sgn is a step function calculated by formula (5).

$\mathrm{Z}$ values are calculated by formula (6):

$$
Z= \begin{cases}\frac{T_{s}-1}{\left.\sqrt{V A R\left(T_{s}\right.}\right)}, & T_{s}>0 \\ 0, & T_{s}=0 \\ \frac{T_{s}+1}{\sqrt{\operatorname{VAR}\left(T_{s}\right)}}, & T_{s}<0\end{cases}
$$

where $\operatorname{VAR}\left(T_{\mathrm{s}}\right)=(n(n-1)(2 n+5)) / 18$ is the variance in $\mathrm{T}_{\mathrm{S}}$ and $n$ is the number of data points in the sequence.

At a $95 \%$ confidence level, the threshold value of $Z$ is 1.96 , and the combinations of the $Z$ value and Sen slope are shown in Table 3.

The Hurst exponent is an index to describe the self-similarity and long-term dependence of natural phenomena. It is a mathematical tool to analyse the long-lasting nature and correlation of natural phenomena. It is widely used in hydrology, climate, and other fields [14-16]. Previous studies have shown that the Hurst exponent based on the rescaled range $(\mathrm{R} / \mathrm{S})$ is more stable than other methods [17]. Therefore, we selected the Hurst exponent to analyse the continuity in NDVI trends from 2000 to 2020.

There are $\mathrm{NDVI}_{i}$, NDVI time series, where $i=1,2$, $3,4 \ldots \mathrm{N}$. This time series is defined for any positive

Table 3 Interpretation of Sen and Mann-Kendall test model results

\begin{tabular}{lll}
\hline Trend analysis & Sen $>\mathbf{0}$ & Sen $<\mathbf{0}$ \\
\hline$|Z|>1.96$ & $\begin{array}{c}\text { Significant increase (S } \\
\text { increase) }\end{array}$ & $\begin{array}{c}\text { Significant } \\
\text { decrease (S } \\
\text { decrease) }\end{array}$ \\
$|Z|<1.96$ & Non-significant increase & Non- \\
& (NS increase) & significant \\
& decrease \\
& (NS \\
& decrease)
\end{tabular}


integer $m$. The procedure for calculating the Hurst method is as follows:

(1) Differential sequence

$$
\Delta \mathrm{NDVI}_{i}=\mathrm{NDVI}_{i}-\mathrm{NDVI}_{i-1}
$$

(2) Mean sequence

$$
\begin{aligned}
& \overline{\Delta \mathrm{NDVI}(m)}=\frac{1}{m} \sum_{i=1}^{m} \Delta \mathrm{NDVI} \\
& (m=1,2, \ldots, n)
\end{aligned}
$$

(3) Cumulative deviation

$$
\begin{aligned}
X(t)= & \sum_{i=1}^{m}\left(\Delta \mathrm{NDVI}_{i}-\overline{\Delta \operatorname{NDVI}(m)}\right) \\
& (1 \leqslant t \leqslant m)
\end{aligned}
$$

(4) Range

$$
\begin{aligned}
R(m)= & \max _{1 \leqslant m \leqslant n} X(t)-\min _{1 \leqslant m \leqslant n} X(t) \\
& (m=1,2, \ldots, n)
\end{aligned}
$$

(5) Standard deviation

$$
\begin{aligned}
S(m)= & {\left[\frac{1}{m} \sum_{i=1}^{m}\left(\Delta \mathrm{NDVI}_{i}-\overline{\Delta \operatorname{NDVI}(m)}\right)^{2}\right]^{\frac{1}{2}} } \\
& (m=1,2, \ldots, n)
\end{aligned}
$$

(6) Hurst exponent $(\mathrm{H})$

$$
\begin{aligned}
H(m)= & \frac{R(m)}{S(m)} \\
& (m=1,2, \ldots, n)
\end{aligned}
$$

There are three types of Hurst exponents with a range from 0 to 1 in Table 4. When $\mathrm{H}<0.5$, the future trend is expected to be reversed from the past trend. When $0.5<\mathrm{H}<0.65$, the process has a continuous characteristic, and the future trend may be consistent with the past trend. When $\mathrm{H}>0.5$, the process has a continuous characteristic, and the future trend is highly likely to be consistent with the past trend.

\section{Results}

\section{NDVI trends on Rennell Island}

The Sen + Mann-Kendall analysis method was selected to determine the distribution of the changing NDVI trends on Rennell Island from 2000 to 2020 (Fig. 3). The overall change trend of Rennell Island was not significant, and the mean Sen trend was $-0.1 \times 10^{-4}$. Increasing change trend values were observed for $50 \%$ of the study area, and areas with decreasing change trends accounted for $49.9 \%$ of the total study area. The Mann-Kendall test results indicated that there were significant changes in $5.7 \%$ of the study area, while nonsignificant changes occurred in $94.1 \%$ in the study area. Areas with slight degradation accounted for $47.1 \%$ of the total study area, and areas with slight improvements accounted for $47.0 \%$ of the study area. Slight degradation was the dominant type of change on West Rennell Island. These results combined with Google Earth images indicate that most of the areas where degradation occurred were in or near human settlements, which indicates that human activities, especially mining, deforestation, construction, and other disruptive activities on the island, likely had a significant disruptive impact on the vegetation. Overall, the change trend indicated that the vegetation on East Rennell Island was slightly improved. The areas with degraded vegetation were largely distributed near Lake Tengano; the destruction was evident and continuous in this area, mainly near facilities and constructed structures along the lake.

\section{NDVI future trend forecast for Rennell Island}

We used the Hurst exponent formula to obtain the distribution of persistent characteristics reflecting NDVI changes on Rennell Island from 2000 to 2020 (Fig. 4). The Hurst values ranged from 0.097 to 0.725 , with a mean of 0.403 . The Hurst values were classified into the following categories: anti-continuity $(\mathrm{AC})(\mathrm{H}<0.5)$, moderate continuity $(\mathrm{MC})(0.5<\mathrm{H}<0.65)$ and high continuity $(\mathrm{HC})(\mathrm{H}>0.65)$. The $\mathrm{AC}$ in the NDVI values on Rennell Island was strong, accounting for $86.5 \%$ of the study area. In general, the AC characteristics indicated that the vegetation in Rennell Island's ecological environments was unstable, which means that external disturbances were frequent from 2000 to 2020 and that further ecological restoration efforts are needed to ensure that the vegetation system will improve. Both the East and West Rennell Islands were dominated by areas of $\mathrm{AC}$, and there was no significant feature

Table 4 Interpretation of the Hurst exponent

\begin{tabular}{llll}
\hline Hurst range & $\mathbf{0}<\mathrm{H}<0.5$ & $0.5<\mathrm{H}<0.65$ & $0.65<\mathrm{H}<1$ \\
\hline Continuity & Anti-continuity sequence & Moderate-continuity sequence & High-continuity sequence \\
\hline
\end{tabular}




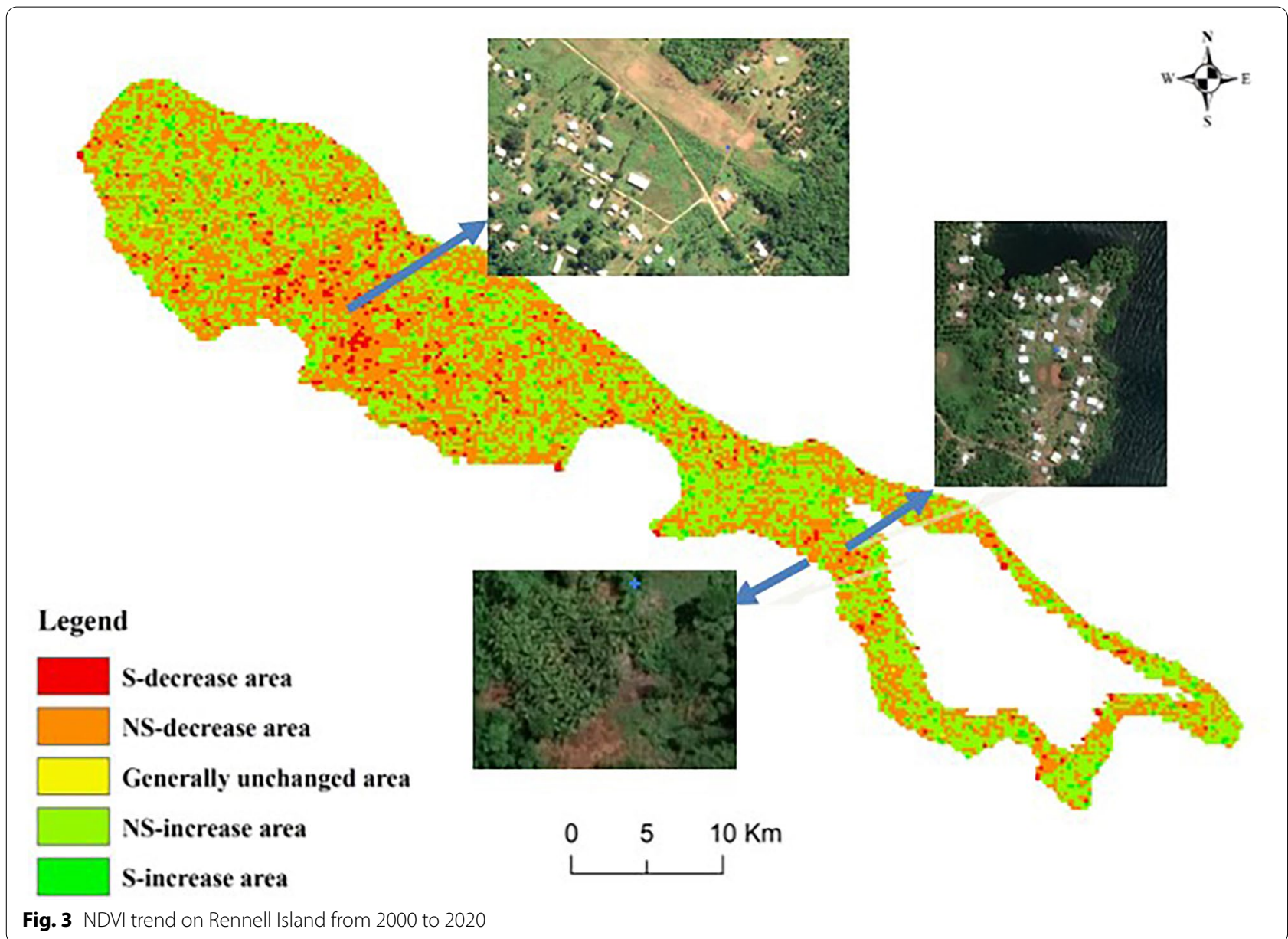

in the continuity distribution. To further analyse the change trend and persistence of vegetation on Rennell Island, the Sen trend calculation result and Hurst index were superimposed for analysis (Fig. 5), and the data were divided into nine classes. The overlap results showed that for most areas of Rennell Island, it will be difficult to sustain previous trends in future NDVI changes (Table 5). The areas with persistent increases and decreases in the AC of NDVI accounted for $6.5 \%$ and $43.0 \%$ of the total area, respectively; these areas are located mainly in the southwestern part of the island, where the vegetation cover is likely to improve in the future. The areas with unchanged NDVI, indicating AC, account for only $0.1 \%$ of the study area; future vegetation change trends in these areas will depend on external disturbances. In the future, the vegetation cover of southwestern Rennell Island may be improved; that is, trends of continuous improvement in NDVI and AC of degradation are mainly distributed in this area. These results suggest that in the future, the vegetation along the inner side of the lake on East Rennell Island may face degradation.

\section{Forest/vegetation cover change on Rennell Island}

Due to the data acquisition period and data quality constraints, fewer images of Rennell Island were available per year between 2012 and 2018. Data from the Landsat series with a spatial resolution of $30 \mathrm{~m}$ were used to extract and calculate the spatial distribution of forest/ vegetation cover change (Fig. 6) and change on Rennell Island from 2012 to 2018 (Fig. 7). The red, yellow, and dark green patches in Fig. 6 show the forest vegetation cover changes caused by agriculture, village and infrastructure construction, deforestation, mining activities, typhoons, and other natural disasters.

Disturbance to forest cover within the ERWHS was much less than that outside of the site; disturbances within the ERWHS at higher elevations along the periphery of the island were probably due to storms and other natural factors, while disturbances closer to Lake Tengano were most likely due to use of forests by communities to meet their essential daily needs. 


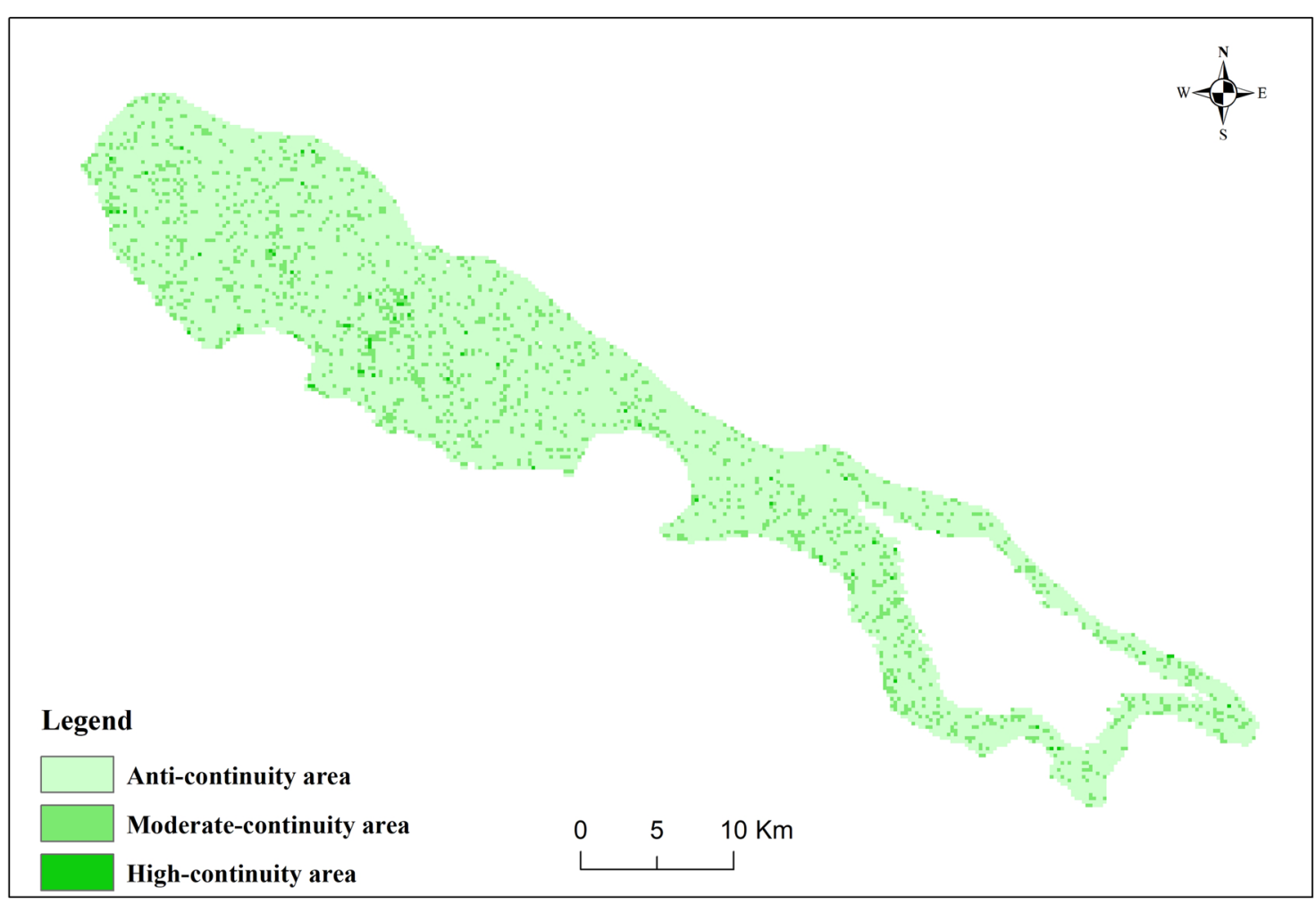

Fig. 4 Spatial distribution of continuity on Rennell Island from 2000 to 2020 based on Hurst exponential data

The Solomon Islands Government has restricted felling activities and mining concessions to residents, but the significant changes in the yellow patches (roads) suggest that road construction for timber transport is likely to be the most significant factor in forest vegetation degradation. The red patches in Fig. 6 are traces of slash-and-burn agriculture, and the locations and extents of the red areas changed annually from 2012 to 2018; the land was used for agriculture for three years after forest reclamation, after which it went into a fallow period to support land restoration. Planting cypress can lead to fast vegetation recovery, but it is necessary for areas to recover to the same forest communities that were present before disturbances, a process that can take decades.

The results of those analyses suggest that the areas with the most intense vegetation changes are in the northwestern part of the island, which is known to be the inhabited area of the island, mainly due to extensive deforestation by residents to meet their daily needs. The whole island is a natural ecosystem, and vegetation cover changes on the western part of the Rennell Islands will inevitably affect the island's environment.

\section{Land cover classification based on Worldview images}

To further analyse the land cover of Rennell Island, a detailed classification of land cover in the study area was performed using a mosaic of 20 images from 19 March 2014 to 3 October 2015 covering the entire island (Figs. 7 and 8).

Despite widespread human disturbances to forest cover on West Rennell Island, the undisturbed forest area still exceeded $90 \%$ of the study area. Undisturbed forest accounted for $52 \%$ of the area on East Rennell Island, while Lake Tengano accounted for 44.73\%; in fact, undisturbed forest accounted for more than $95 \%$ of the East Rennell Island land area. Therefore, $93 \%$ of the land area on Rennell Island was undisturbed forests (see Table 6).

Our Worldview image-based land classification was used to identify similar areas in Landsat images. Comprehensive comparative analysis using high-resolution Worldview and Landsat 8 data showed that the proportions of land with the highest vegetation coverage and high vegetation coverage were significantly greater than that with low vegetation coverage (Fig. 9). The 2014 land cover data were consistent with the results of annual Landsat 8 monitoring data, which confirms that the vegetation cover on Rennell Island was restored to the 


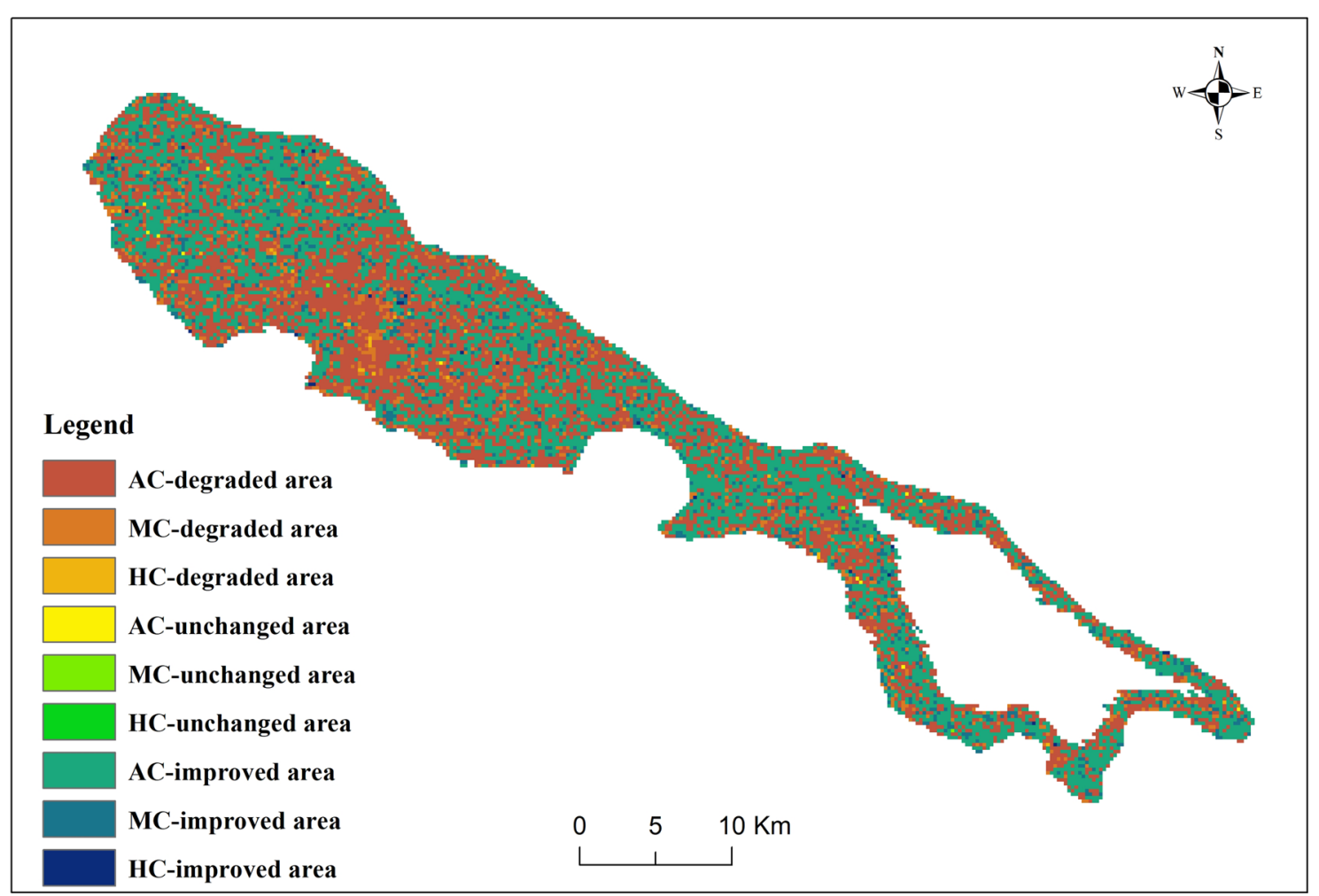

Fig. 5 Continuity distribution of vegetation change on Rennell Island from 2000 to 2020

Table 5 Monitoring the vegetation change on Rennell Island from 2000 to 2020

\begin{tabular}{|c|c|c|c|c|c|}
\hline \multicolumn{4}{|c|}{ Detection of vegetation change in heritage sites from 2000 to 2020} & \multicolumn{2}{|l|}{ Future trend forecast } \\
\hline S decreasing area & $2.9 \%$ & Degradation & $50.0 \%$ & AC degradation area & $43.0 \%$ \\
\hline \multirow[t]{2}{*}{ NS decreasing area } & $47.1 \%$ & & & MC degradation area & $6.7 \%$ \\
\hline & & & & HC degradation area & $0.3 \%$ \\
\hline \multirow[t]{3}{*}{ Unchanging area } & $0.1 \%$ & No change & $0.1 \%$ & AC unchanging area & $0.1 \%$ \\
\hline & & & & MC unchanging area & $0.0 \%$ \\
\hline & & & & $\mathrm{HC}$ unchanging area & $0.0 \%$ \\
\hline \multirow[t]{2}{*}{ NS increasing area } & $47.0 \%$ & Improvement & $49.9 \%$ & AC improving area & $43.4 \%$ \\
\hline & & & & MC improving area & $6.3 \%$ \\
\hline S increasing area & $2.9 \%$ & & & $\mathrm{HC}$ improving area & $0.2 \%$ \\
\hline
\end{tabular}

maximum extent in the second year following its inclusion on the list of endangered heritage sites.

\section{Discussion}

\section{Factors that induced vegetation changes}

The following forest or vegetation cover changes are worth examining: the most intensive forest cover disturbances occurred in the northernmost parts of the island, forests were opened up by local communities for slashand-burn agriculture and for harvesting wood to meet the needs of local residents, such as boat and housing construction, and slash-and-burn agriculture was rare within the ERWHS. Some of the larger forest clearings during specific years were attributable to temporally limited activities or events. For example, the large but dispersed patches of cleared forest in the middle of the island in 2001 were linked to port construction and associated development of settlements and villages. There was significant damage due to storms in 2003, while 2007 was a very dry year, leading to considerable burning of 

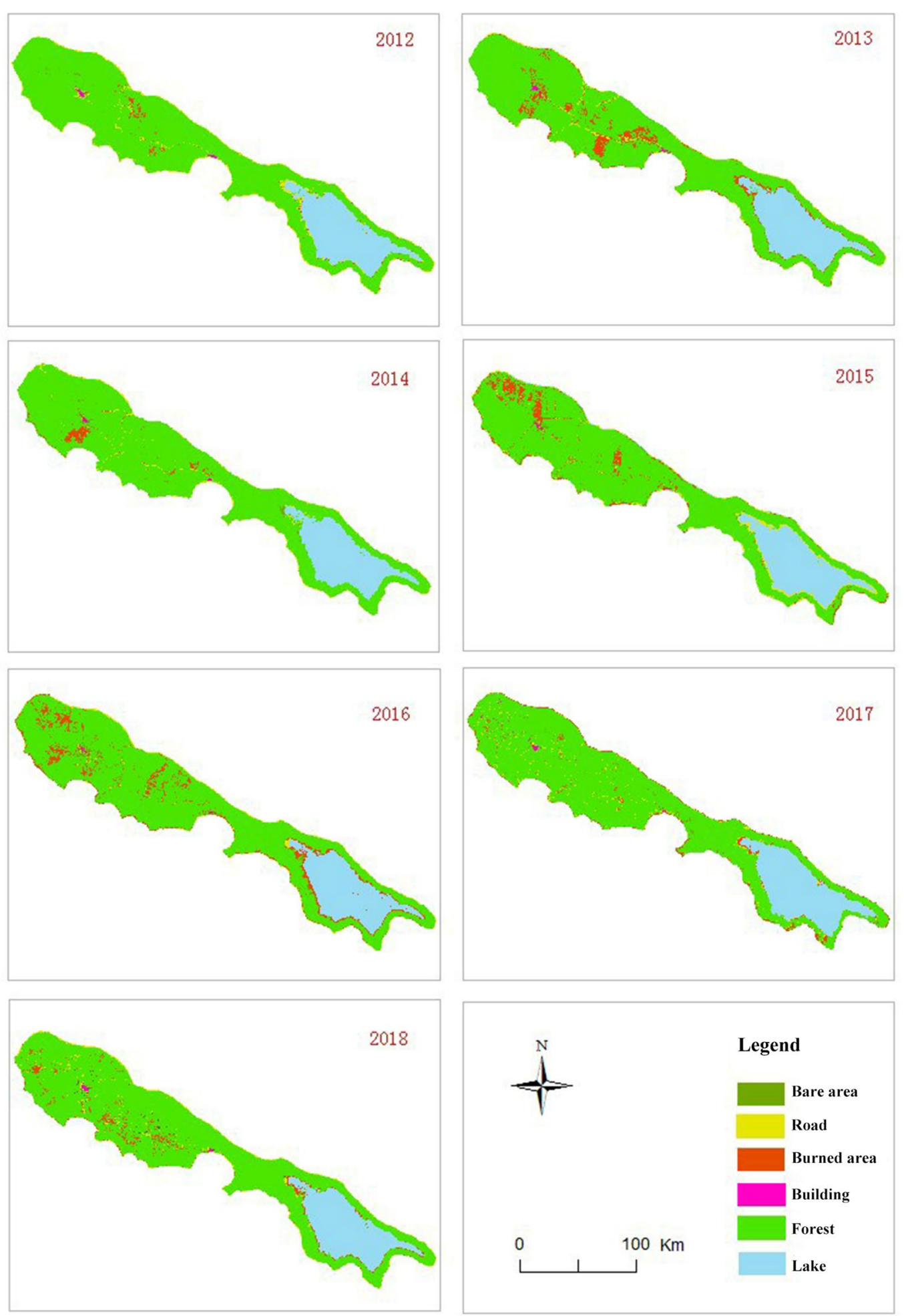

Fig. 6 Changes in forest cover from 2012 to 2018 


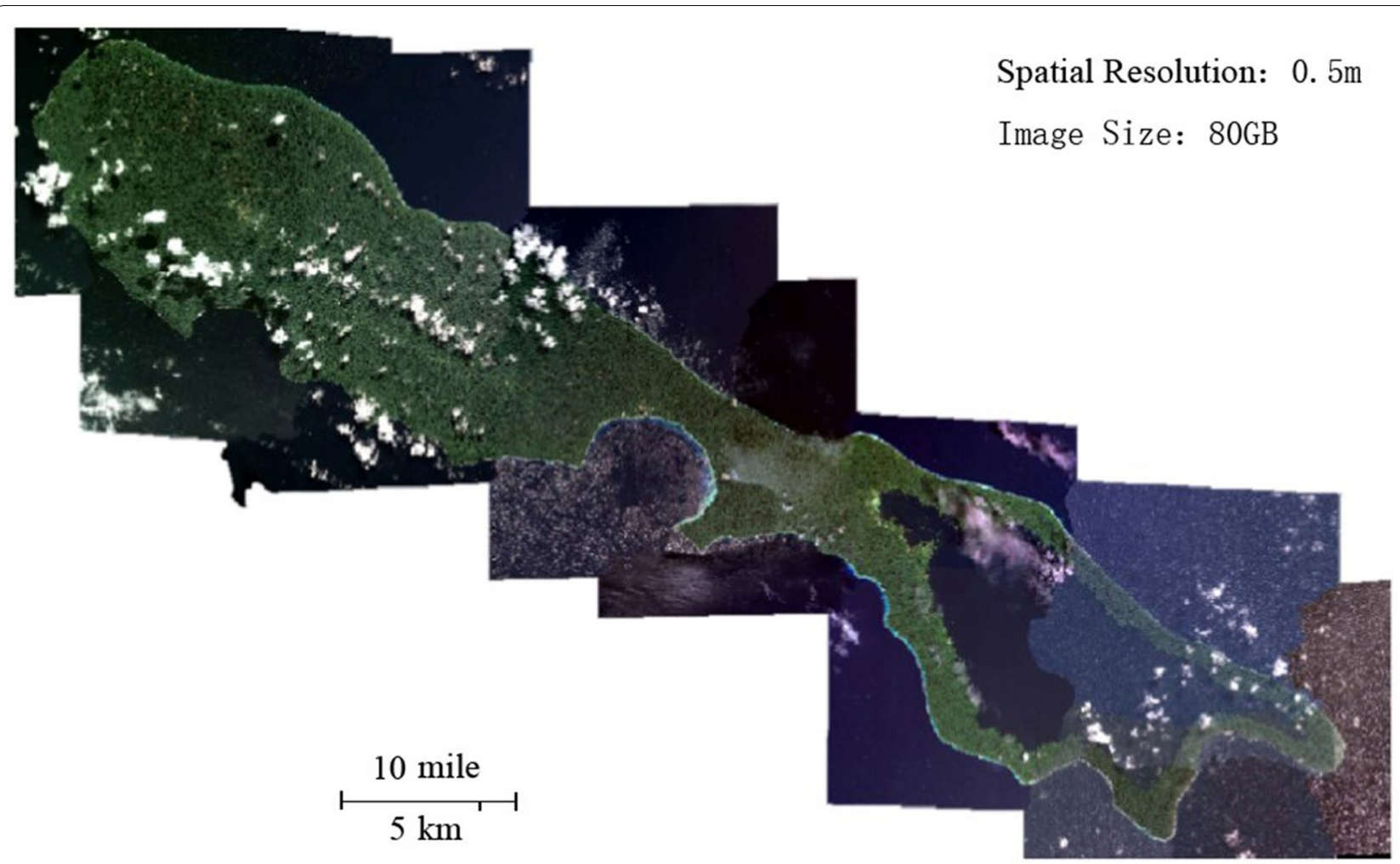

Fig. 7 Worldview images covering Rennell Island

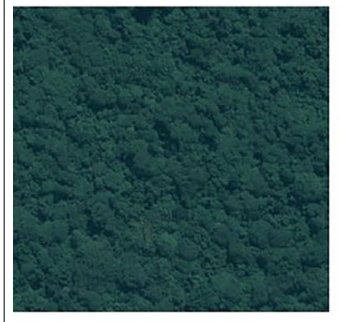

Undisturbed forest

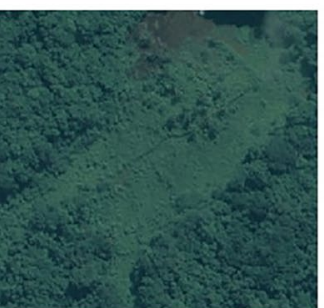

Farmland

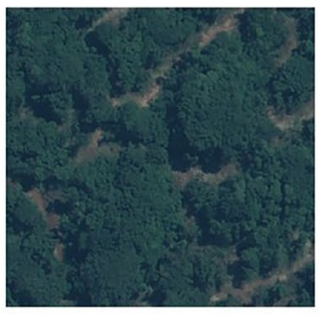

Un-reclaimed forest

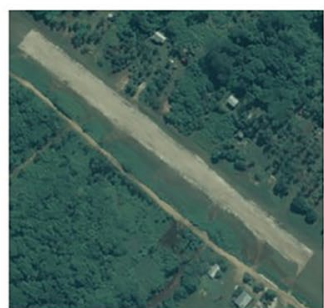

Airport

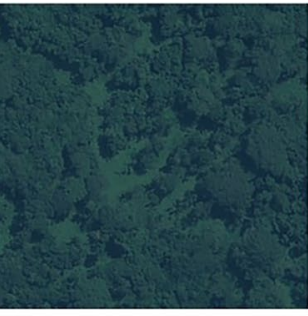

Reclaimed forest

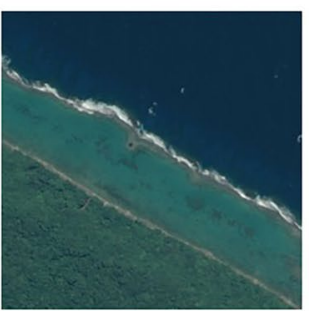

coast

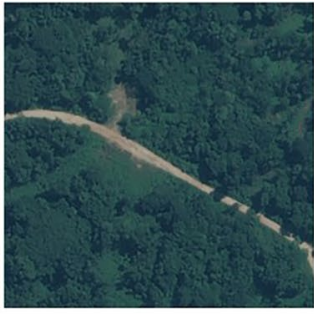

Road

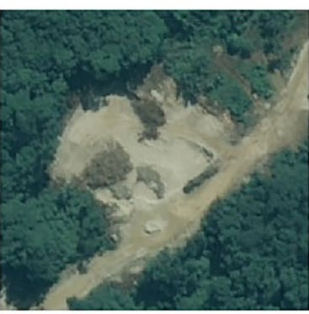

Bare land

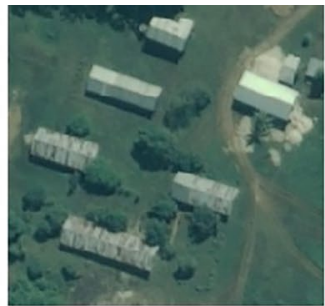

Building

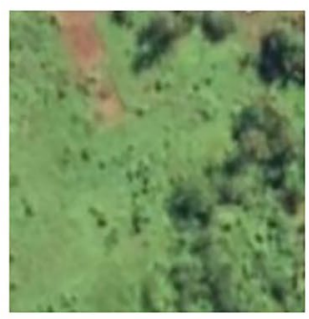

Grass Land

Fig. 8 Categories in the land cover classification system 
Table 6 Percentages of land cover types for West Rennell Island, East Rennell Island (ERWHS) and Rennell Island as a whole

\begin{tabular}{|c|c|c|c|c|c|c|}
\hline \multirow[t]{2}{*}{ Type } & \multicolumn{2}{|c|}{ West Rennell Island } & \multicolumn{2}{|c|}{ East Rennell Island } & \multicolumn{2}{|c|}{ Rennell Island } \\
\hline & Area $\left(\mathrm{km}^{2}\right)$ & Percent (\%) & Area $\left(\mathrm{km}^{2}\right)$ & Percent (\%) & Area $\left(\mathrm{km}^{2}\right)$ & Percent (\%) \\
\hline Undisturbed forest & 443.83 & 92.34 & 187.76 & 52.53 & 631.59 & 75.36 \\
\hline Reclaimed forest & 18.62 & 3.87 & 0 & 0 & 18.62 & 2.22 \\
\hline Farmland & 4.76 & 0.99 & 3.04 & 0.85 & 7.8 & 0.93 \\
\hline Un-reclaimed forest & 3.84 & 0.8 & 0 & 0 & 3.84 & 0.46 \\
\hline Grassland & 0.16 & 0.03 & 0.05 & 0.02 & 0.21 & 0.03 \\
\hline Bare land & 0.73 & 0.15 & 0.1 & 0.03 & 0.84 & 0.10 \\
\hline Building & 0.07 & 0.02 & 0.03 & 0.01 & 0.11 & 0.01 \\
\hline Road & 1.11 & 0.23 & 0.11 & 0.03 & 1.22 & 0.15 \\
\hline Waterbody & 0 & 0 & 159.89 & 44.73 & 159.89 & 19.08 \\
\hline Coast & 7.47 & 1.55 & 6.5 & 1.82 & 13.96 & 1.67 \\
\hline Airport & 0.05 & 0.01 & 0 & 0 & 0.05 & 0.01 \\
\hline
\end{tabular}

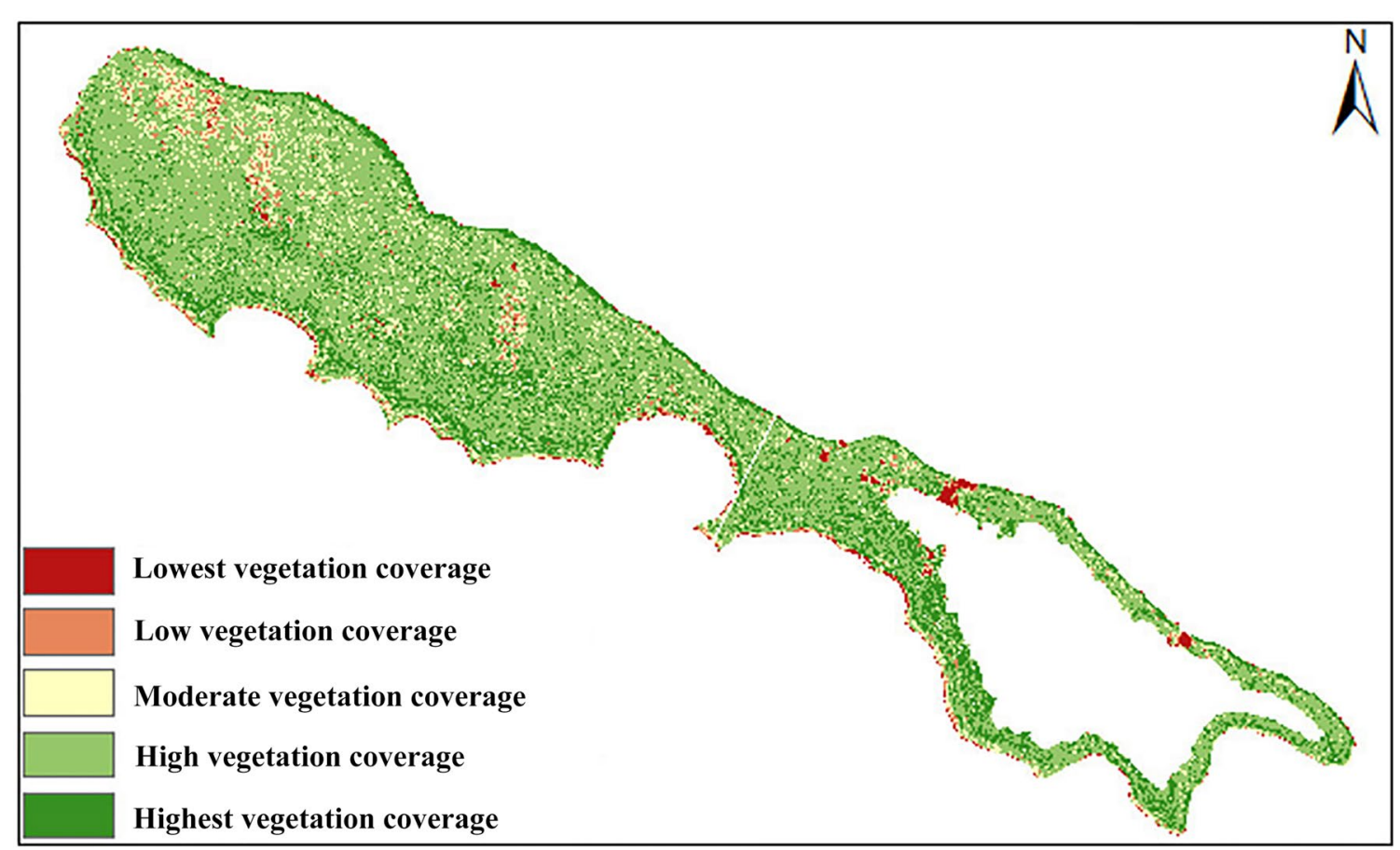

Fig. 9 Vegetation coverage on Rennell Island

forests. The results of the analysis for 2000 to 2020 are as follows:

(1) The area of vegetation cover on Rennell Island decreased: the areas of increasing cover were rough equal to the areas of decreasing cover, but the overall change was not significant and weak. Large areas were covered by undisturbed forest, and the ability of the forest to recover after destruction was strong. The undisturbed or unspoiled forest areas in Ren- nell remained large and contiguous. Within the ERWHS, forest cover accounted for over $95 \%$ of the land area. However, the vulnerability of the study area increased in response to mining and logging activities.

(2) The destruction of forests on the island was mainly due to the activities of residents and natural disasters. Road construction became the primary cause of forest vegetation destruction. The government restricted mining activities in forest areas cleared 
for agriculture and will not develop new mining areas [18].

\section{Suggestions}

When planning and managing forests, consideration must be given to sustainable connectivity and forest cover contiguity in key areas. The timing of the removal of the ERWHS from the list of endangered World Heritage Sites must also be considered in the context of the state party and community interests, since improving the conservation status of the area and generating livelihood options and income are compatible with conservation. The removal of the ERWHS from the list of endangered World Heritage Sites is dependent on the removal of all threats to the site [19], and the time needed to achieve such complete elimination is likely to be quite long. For the state party, it would be helpful if the ERWHS were removed from the list of endangered World Heritage Sites as soon as the plan and timeframe for the mitigation of all prevailing threats to the conservation of the site have been reviewed and approved by the World Heritage Committee and regular monitoring of the implementation of the plan by UNESCO and International Union for the Conservation of Nature (IUCN) has been established.

The following suggestions were made on the basis of the results of the data analyses:

(1) A land cover classification comprising 10 categories was established (see Fig. 8) for all of Rennell Island based on high-resolution Worldview images (0.5-2 m resolution) from 2014-2015. The World Heritage Centre and IUCN could use satellite remote sensing data as the baseline for future forest cover monitoring on Rennell Island.

(2) Currently, there is no buffer zone demarcated for the ERWHS. The need to demarcate a buffer zone extending up to a specific distance from the current western boundary of the ERWHS into western parts of the island has been made clear; however, the establishment of this boundary will involve complex and challenging negotiations among the community owning land immediately outside the western boundary of the ERWHS, the residents of communities within the ERWHS and national and provincial government authorities. A buffer zone within which economic activities such as forestry and agriculture are prohibited will be difficult to establish via negotiations. Furthermore, for the buffer zone to be established in such a way that the connectivity of forests between the ERWHS and the western parts of the island is ensured, considerable new data on the distribution and population status of land-based avian and invertebrate endemic animals that occur within the ERWHS are needed. The allocation of other land use types must consider the entire island's connectivity and the forest cover in key areas [20].

(3) The key factor for the protection of the natural heritage site on Rennell Island lies in its forest resources. The protection of the forest will not only promote natural restoration of the ecological environment but also protect the resources of the island through active policy programmes. At present, the main conflict lies in the interests of landowners and the forest protection requirements of natural heritage sites [12]. The intended nationally determined contributions (INDCs) of the Solomon Islands were discussed at the 21st session of the UN Framework Convention on Climate Change (UNFCCC), and the importance of land use, land use change, and forestry sectors, particularly for climate change adaptation and minimizing greenhouse gas emissions, were mentioned. Thus, the Global Climate Fund could provide potential financing for sustainable forestry development on Rennell Island.

\section{Conclusions}

Although the vegetation on Rennell Island has a high regeneration capacity, its growth status is unstable, and human intervention is key to conservation efforts [21, 22].

HIST's space technology applications have achieved gratifying results at this endangered heritage site. Following HIST's recommendations, the Solomon Islands Government announced its decision to revoke and/or refuse to grant any felling licence within the ERWHS in August 2017, thus temporarily banning all logging on the site [23]. While this measure serves as a temporary solution, in the longer term, it will be important to introduce a legal mechanism, such as an application to be submitted by landowners, to designate property under the Protected Areas Act and adopt the management plan of this act, which would protect the property from commercial logging [24].

The core phrase of the world heritage designation is "outstanding universal value," and its constituent elements, verification of authenticity and integrity and effective protection and management mechanisms, indicate the standards of world heritage Sites [22]. Space technologies can be applied to identify the features and statuses of ground objects macroscopically, quickly and accurately. Satellite navigation and positioning technology can be applied to accurately locate sites, and geographic information technology can be applied to quickly and 
effectively perform spatial analyses. These cutting-edge spatial information technologies have proven advantages in the protection of archaeological and heritage sites.

\author{
Abbreviations \\ ha: Hectare; UNESCO: United Nations Educational, Scientific and Cultural \\ Organization; km: Kilometres; NDVI: Normalized difference vegetation index; \\ IUCN: International Union for the Conservation of Nature; MODIS: Moderate- \\ resolution imaging spectroradiometer.
}

\section{Acknowledgements}

We sincerely acknowledge the constructive comments and suggestions given by Prof. Fu Bihong from HIST, which helped to greatly improve the manuscript.

\section{Authors' contributions}

Conceptualization, SH; methodology, MW and GC; software, HS and RY; validation, GC; formal analysis, MW and GC; writing - original draft preparation, SH; writing — review and editing, SH and GC. All authors read and approved the final manuscript.

\section{Funding}

This research was funded by the Netherlands Funds-in-Trust (NFiT) of the UNESCO World Heritage Center and a subproject of the Earth, Big Data, Science and Engineering pilot project by the Chinese Academy of Sciences (XDA19030501)

\section{Availability of data and materials}

The authors confirm that data supporting the findings of this study are available. The MODIS 16-day L3 global $250 \mathrm{~m}$ vegetation indices were obtained from the Earth Science Data Systems (ESDS) Program of the National Aeronautics and Space Administration (NASA) (https://search.earthdata.nasa. gov/search?q=MOD13Q1). The Landsat 8 images were obtained from NASA (https://glovis.usgs.gov/). The Worldview image data were provided by HIST.

\section{Declarations}

\section{Competing interests}

The authors declare no conflicts of interest.

\section{Author details}

${ }^{1}$ International Centre on Space Technologies for Natural and Cultural Heritage, The Aerospace Information Research Institute, Chinese Academy of Sciences, Beijing 100094, China. ${ }^{2}$ University of Chinese Academy of Sciences, Beijing 100049, China. ${ }^{3}$ China University of Geosciences, Wuhan 430072, China.

Received: 26 April 2021 Accepted: 11 August 2021

Published online: 24 August 2021

\section{References}

1. Levin N, Ali S, Crandall D, Kark S. World Heritage in danger: Big data and remote sensing can help protect sites in conflict zones. Glob Environ Chang. 2019;55:97-104.

2. Pałaś KW, Zawadzki J. Sentinel-2 imagery processing for tree logging observations on the białowieża forest world heritage site. Forests. 2020;11(8):857.

3. Yao Y, Wang X, Lu L, Liu C, Wu Q, Ren H, et al. Proportionated distributions in spatiotemporal structure of the world cultural heritage sites: analysis and countermeasures. Sustain Basel. 2021;13(4):2148.

4. World Heritage Site website. https://whc.unesco.org/en/danger/. Accessed 20 April 2021.
5. Wang M, He G, Ishwaran N, Hong T, Bell A, Zhang Z, et al. Monitoring vegetation dynamics in East Rennell Island World Heritage Site using multi-sensor and multi-temporal remote sensing data. Int J Digit Earth. 2018;13(3):393-409.

6. World Heritage Site website. http://whc.unesco.org/en/list/854/. Accessed 20 April 2021.

7. Shiels AB, Pitt WC, Sugihara RT, Witmer GW. Biology and Impacts of Pacific Island Invasive Species. 11. Rattus rattus, the Black Rat (Rodentia: Muridae). Pac Sci. 2014;2(68):145-84

8. Loveridge R, Wearn OR, Vieira M, Bernard H, Ewers RM. Movement behavior of native and invasive small mammals shows logging may facilitate invasion in a tropical rain forest. Biotropica. 2016;48(3):373-80.

9. Chen F, Guo H, Ma P, Lin H, Wang C, Ishwaran N, et al. Radar interferometry offers new insights into threats to the Angkor site. Sci Adv. 2017;3(3):e1601284.

10. Erasmi S, Klinge M, Dulamsuren C, Schneider F, Hauck M. Modelling the productivity of Siberian larch forests from Landsat NDVI time series in fragmented forest stands of the Mongolian forest-steppe. Environ Monit Assess. 2021. https://doi.org/10.1007/s10661-021-08996-1.

11. Fernández-Guisuraga JM, Calvo L, Suárez-Seoane S. Comparison of pixel unmixing models in the evaluation of post-fire forest resilience based on temporal series of satellite imagery at moderate and very high spatial resolution. Isprs J Photogramm. 2020;164:217-28.

12. SPC/GIZ. 2013. REDD Feasibility Study for East Rennell World Heritage Site, Solomon Islands. A joint study conducted by the Secretariat of the Pacific Community (SPC) and the German Technical Agency GIZ. SPC/GIZ Regional REDD Project, Suva, Fiji. 41 pages including annexes.

13. Liu Q, Wang X, Zhang Y, Zhang H, Li L. Vegetation degradation and its driving factors in the farming-pastoral ecotone over the countries along belt and road initiative. Sustain Basel. 2019;11(6):1590.

14. Wang Y, Liu X, Ren G, Yang G, Feng Y. Analysis of the spatiotemporal variability of droughts and the effects of drought on potato production in northern China. Agr Forest Meteorol. 2019;264:334-42.

15. Jovanovic D, Jovanovic T, Mejía A, Hathaway J, Daly E. Technical note: long-term persistence loss of urban streams as a metric for catchment classification. Hydrol Earth Syst Sc. 2018;22(6):3551-9.

16. Na L, Na R, Zhang J, Tong S, Shan Y, Ying H, et al. Vegetation dynamics and diverse responses to extreme climate events in different vegetation types of inner mongolia. Atmosphere Basel. 2018;9(10):394.

17. Hott MC, Carvalho LMT, Antunes MAH, Resende JC, Rocha WSD. Analysis of grassland degradation in zona da mata, MG, brazil, based on NDVI time series data with the integration of phenological metrics. Remote SensBasel. 2019;11(24):2956.

18. Grech A, Pressey RL, Day JC. Coal, cumulative impacts, and the great barrier reef. Wiley (10.1111). 2016;200-208(9).

19. UN-REDD Programme. http://www.un-redd.org/. Accessed 20 April 2021.

20. Furusawa T, Sirikolo MQ, Sasaoka M, Ohtsuka R. Interaction between forest biodiversity and people's use of forest resources in Roviana, Solomon Islands: implications for biocultural conservation under socioeconomic changes. J Ethnobiol Ethnomed. 2014;10:10.

21. World Heritage Site website. http://whc.unesco.org/en/news/1948/. Accessed 20 April 2021.

22. Dingwall P. Report on the Reactive Monitoring Mission to East Rennell, Solomon Islands, IUCN Gland.2013. https://whc.unesco.org/en/docum ents/122248/. Accessed 21 April 2021.

23. World Heritage Site website. http://whc.unesco.org/en/news/1719/. Accessed 20 April 2021.

24. World Heritage Site website. http://whc.unesco.org/en/news/1934/. Accessed 20 April 2021

\section{Publisher's Note}

Springer Nature remains neutral with regard to jurisdictional claims in published maps and institutional affiliations. 